\title{
Paleoenvironment and chemostratigraphy heterogenity of the Cretaceous organic-rich shales
}

\author{
Modi Guan ${ }^{1,2}$, Songtao $\mathrm{Wu}^{2,3,4 \oplus *}$, Lianhua $\mathrm{Hou}^{2,3 \odot *}$, Xiaohua Jiang ${ }^{2,3,4}$, Dan $\mathrm{Ba}^{2}$, Ganlin Hua $\mathrm{Hu}^{2,5}$ \\ ${ }^{1}$ School of Earth and Planetary Sciences, University of Chinese Academy of Sciences, Beijing 10083, P. R. China \\ ${ }^{2}$ Research Institute of Petroleum Exploration and Development, PetroChina, Beijing 100083, P. R. China \\ ${ }^{3}$ National Energy Tight Oil and Gas Research and Development Centre, Beijing 100083, P. R. China \\ ${ }^{4}$ Key Laboratory of Oil and Gas Reservoirs, CNPC, Beijing 100083, P. R. China \\ ${ }^{5}$ School of Energy Resources, China University of Geosciences (Beijing), Beijing 100083, P. R. China
}

Keywords:

Shale oil

sweet-spot

nano-pore

Paleoenvironment reconstruction

\section{Cited as:}

Guan, M., Wu, S., Hou, L., Jiang, X., Ba, D., Hua, G. Paleoenvironment and chemostratigraphy heterogenity of the Cretaceous organic-rich shales. Advances in Geo-Energy Research, 2021, 5(4): 444-455, doi: 10.46690/ager.2021.04.09

\begin{abstract}
:
The Cretaceous Qingshankou Formation in the Songliao Basin is rich in shale oil resources, which has become one of the most important exploration targets of lacustrine shale oil in China. Based on X-ray fluorescence element analysis, X-ray diffraction analysis, total organic carbon, rock pyrolysis, scanning electron microscope and nitrogen adsorption, the Paleoenvironment was reconstructed by comprehensive utilization of integrated prediction error filter analysis of chemical stratigraphy, and its relationship with organic geochemistry, mineralogy and pore structure was discussed. The results indicated that the Qingshankou Formation was deposited in the environment with fresh water-brackish water, semideep/deep water and strong reduction. The evolution of Paleoenvironment during the deposition of Qingshankou Formation changed from bottom to top, with increasing water depth, decreasing salinity and oxygen content. Paleosalinity was positively correlated with total organic carbon, residual hydrocarbon and carbonate mineral content. From bottom to top, the contents of carbonate and chlorite decreased, while the contents of plagioclase and clay minerals increased slightly. The pores were dominated by intra-illite pores, intraI/S mixed-layer pores and intra-pyrite pores. Some intra-plagioclase pores and calcite dissolution pores were developed, and the organic matter pores are slightly few. Nitrogen adsorption data showed that the dominate pore size was $40-53 \mathrm{~nm}$. This study clarifies the Paleoenvironmental evolution of the Qingshankou Formation, and may shed lights on lacustrine shale oil accumulation and sweet-spotting.
\end{abstract}

\section{Introduction}

The marine shale revolution in North America has successfully changed the energy pattern of the North America and profoundly affected the global political and economic ecology (Zhi et al., 2019). China's oil and gas exploration is now transitioning from dominance of conventional oil and gas to equal importance of conventional and unconventional oil and gas (Feng et al., 2020; Zhao et al., 2020; Zou et al., 2020). As an important part of unconventional oil and gas resources, lacustrine shale oil has now become a research hotspot, and a series of major breakthroughs have been made in lacustrine shale oil in the Junggar Basin, Ordos Basin, Songliao Basin, Bohai Bay Basin and Santanghu Basin (Fu et al., 2019; Wu et al., 2019; Hou et al., 2020, 2021).

The lacustrine shale systems (formation series dominated by shale) in China has extremely strong heterogeneity, and the Paleogeological settings of different basins varies significantly, mainly including the salinized lacustrine basin, the freshwater lacustrine basin, and the lacustrine basin affected by transgression (Zhu et al., 2019; Zou et al., 2020). Differences of Paleoenvironments of lacustrine basins have profound influences upon the lithologic association, diagenetic evolution and reservoir storage capacity of the shale systems, and thus are highlighted by both geologists and oil companies. Previous studies indicated that the Paleoenvironment affects not only the distribution of organic matter but also the physical

\section{Yandy} Scientific Press

${ }^{*}$ Corresponding author.

E-mail address: guanmodi@petrochina.com.cn (M. Guan); wust@petrochina.com.cn (S. Wu); houlh@petrochina.com.cn (L. Hou); jiangxiaohua69@petrochina.com.cn (X. Jiang); badan@petrochina.com.cn (D. Ba); huaganlin@126.com (G. Hua). 2207-9963 (c) The Author(s) 2021.

Received November 15, 2021; revised December 3, 2021; accepted December 4, 2021; available online December 7, 2021.
} 
properties of the reservoir (Manzullo and Harris, 1992). There are obvious differences among shales in different basins $(\mathrm{Wu}$ et al., 2015). The Paleoenvironment factors including the water level fluctuation of the lacustrine basin, and water salinity are significant to the types of biogenic organic matter and sedimentary facies (Liu et al., 2018). Currently, chemostratigraphy is a widely-used Paleoenvironment reconstruction technology for both lacustrine and marine basins, of which is to calculate Paleowater depth, temperature, salinity and redox property via elemental analysis (Jones and Manning, 1994; Bohacs et al., 2000; Nicolas et al., 2006). Over recent years, continuous $\mathrm{X}$-ray fluenrence (XRF) element analysis has been widely adopted during the chemostratigraphy study (Koch et al., 2014; Ratcliffe et al., 2015; Attar and Pranter, 2016; Peters et al., 2016; Zhang et al., 2019). The energy dispersive X-ray fluorescence (ED-XRF) analyzer has been proven to be able to provide a robust "first look" for chemostratigraphy based on cores of drilling (Rowe et al., 2011). ED-XRF analysis has three obvious advantages, i.e., (i) non-destructiveness; (ii) high-resolution continuous measurement, comparable with well logging data; (iii) fast operation and low cost. For example, Liu et al. (2018) and Fu et al. (2019) reconstructed the Paleoenvironments of the Permian Lucaogou Formation in the Junggar Basin and the Triassic Chang 7 member in the Ordos Basin, respectively, and investigated the relationship between the Paleoenvironment and hydrocarbon generation potential of organic matter. In general, chemostratigraphy based on XRF continuous elemental scanning has now evolved into an important research orientation.

The organic-rich shales of the Qingshankou Formation are widely distributed across the Qijia-Gulong Sag in the Songliao Basin. It is one of the most important lacustrine source rocks in China, which provide sufficient hydrocarbon for the long-term production of the Daqing Oilfield and Jilin Oilfield. Many wells drilled into Qingshankou Formation had obtained industrial oil production since 1981, which had attracted high attention from both oil companies and major research institutions (Gao, 1984; Sun et al., 2021). The first well (Well Y12) was drilled in 1981, and another five vertical wells were drilled successively from 1983 to 1991, and the first horizontal well (Well GP1) was carried out in 1998. During 2011-2018, 18 vertical wells, such as Well GY1, YX57 and $\mathrm{C} 21$, and four horizontal wells, including Well PY1HF, PY2HF, GYY1 and YY1H, were deployed for the sweetspotting of the Qingshankou Formation (Sun et al., 2021).

Many scholars have carried out systematic studies on the stratigraphic, petrological, paleontological and organic geochemical characteristics of the first member of the Qingshankou Formation (Gao, 1984; Wang et al., 2008; Sun et al., 2021). Wang and his team had elaborately investigated and discussed the Paleosedimentary environment of the Cretaceous shale in the Songliao Basin, based on continental scientific exploration wells including Well SK1 and Well SK2, and the results has important guiding significance for the further study of Qingshankou Formation (Wang et al., 2008). However, wells SK1 and SK2 are located on the slope of the Songliao Basin, which are far away from the sag center. Therefore, there is big gap for the research on the pelao-environment of the central Songliao Basin.

During 2019-2020, several wells have been drilled in the Gulong Sag to investigate the shale oil potential (Sun et al., 2021), and Well A is the one which is located in the central Songliao Basin. This paper targets on Well A and reconstruct the Paleoenvironment of Qing 1 member, via detailed core description and continuous XRF scanning. Furthermore, the differences of petrology, mineralogy, organic geochemistry, and reservoir properties of different Paleoenvironment units are investigated and discussed. The findings of this research are of great significance for deepening the study on the Paleoenvironment and evaluating reservoir effectiveness of the Qingshankou Formation in the central parts of the Songliao Basin where are the sweet-spots of shale oil.

\section{Geological setting}

The Songliao Basin, with an area of about $2.6 \times 10^{5} \mathrm{~km}^{2}$, is located in the northeastern China. It is one of the most important lacustrine petroliferous basins in the world. The Gulong Sag lies in the western part of the basin, adjacent to the Daqing Placanticline on its east and Longhupao-Daan terrace on its west. It is generally a monocline dipping from northwest to southeast, with an area of about $3700 \mathrm{~km}^{2}$ (Fig. 1), and is a deep-water sag with long-term succession (Fig. $1(\mathrm{a})$ ).

The Songliao Basin was a large lacustrine basin during the Late Cretaceous. The Qingshankou Formation can be divided into three members vertically (Fig. 1(b)), and they are Qing 1 member, Qing 2 member and Qing 3 member from bottom to top (Fig. 1(b)). The organic-rich mudstones and shales are deposited in the Qing 1 member. The vitrinite reflectance could reach $1.20 \%-1.67 \%$, indicating relative high maturity. During deposition of the Qing 1 member, large-scale transgression occurred, which resulted in a semi deep-deep lake reducing environment (Feng et al., 2015). The lacustrine area during deposition of the Qing 1 member was $1 \times 10^{5} \mathrm{~km}^{2}$, and it decreased to $6 \times 10^{4} \mathrm{~km}^{2}$ during the deposition of Qing $2+3$ member. The average thickness of organic-rich shales of Qing 1 member and Qing $2+3$ member are $61.5 \mathrm{~m}$ and 249.04 $\mathrm{m}$, respectively. Preliminary study indicated that the shale oil resources in the Songliao Basin could reach 6 billion tons.

\section{Samples and methods}

This research focuses on Well A, which was specially targeted for the Qing 1 member in the central Songliao Basin (for locations of key wells, please refer to Fig. 1(a)). The thickness of Qing 1 member was $70 \mathrm{~m}$. On the basis of core description, we first carried out XRF continuous scanning (spotting) along the whole core sample. Then, 57 representative samples were selected for investigation of organic geochemistry, mineralogy and pore structures.

\subsection{Paleoenvironment reconstruction based on XRF element analysis}

In this paper, the elemental scanning was performed using the Thermo Scientific Niton XL handheld ED-XRF analyzer, and the spatial resolution is of 3-5 cm (Dean et al., 1997). 

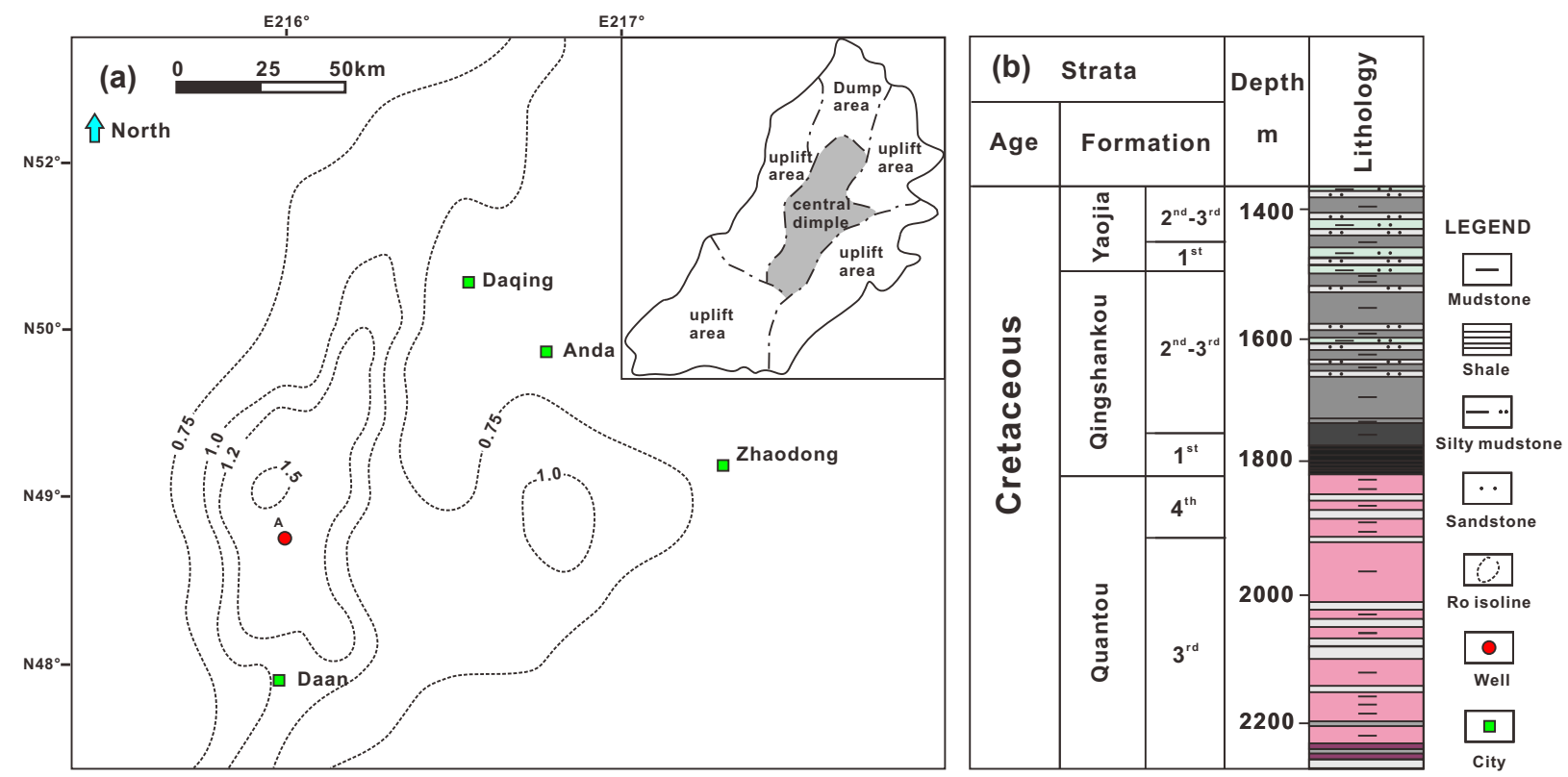

Fig. 1. Study area of the Songliao Basin and locations of key wells. (a): Contour map of thermal maturity distribution of the Gulong Sag; (b): Cretaceous stratigraphic column, showing that the Qing 1 member of the Qingshankou Formation is mainly composed of organic-rich mudstones and shales (modified from Liu et al. (2018), He et al. (2021) and Sun et al. (2021)).

The ED-XRF analyzer has two measurement modes: the soil mode and mining mode. During our measurement process, the soil mode was firstly used, and then switched to the mining mode to collect element measurements. The detection time of the soil mode was set at 60 seconds to detect elements with concentration lower than $1 \%$, while that of the mining mode was set to 120 seconds to detect elements with concentration higher than $1 \%$. The basic data of the two modes were merged during data processing (Dill et al., 1988). The instrument has a built-in calibration system and the unit of measurement is $\mathrm{ppm}$. In this paper, the interval of XRF spotting is $10 \mathrm{~cm} / \mathrm{spot}$, and 387 spots were gained from continuous spotting scanning over $2315-2370 \mathrm{~m}$. The major elements include magnesium $(\mathrm{Mg})$, aluminum $(\mathrm{Al})$, silicon $(\mathrm{Si})$, phosphorus $(\mathrm{P})$, sulfur $(\mathrm{S})$, potassium $(\mathrm{K})$, calcium $(\mathrm{Ca})$, titanium $(\mathrm{Ti})$, manganese $(\mathrm{Mn})$, and iron $(\mathrm{Fe})$, while the trace elements include barium $(\mathrm{Ba})$, vanadium $(\mathrm{V})$, chromium $(\mathrm{Cr})$, nickel $(\mathrm{Ni})$, copper $(\mathrm{Cu})$, zinc $(\mathrm{Zn})$, thorium $(\mathrm{Th})$, rubidium $(\mathrm{Rb})$, uranium $(\mathrm{U})$, strontium $(\mathrm{Sr})$, zirconium $(\mathrm{Zr})$, niobium $(\mathrm{Nb})$, and molybdenum $(\mathrm{Mo})$.

In this paper, the indicators for Paleoenvironment reconstruction, used by Liu et al. (2018) and Fu et al. (2019), were adopted. Specifically, the ratio of $\mathrm{V} / \mathrm{Cr}$ was used as the redox parameter, $\mathrm{Ca} /(\mathrm{Ca}+\mathrm{Fe})$, as the salinity parameter, $(\mathrm{Al}+\mathrm{Fe}) /(\mathrm{Ca}+\mathrm{Mg})$, as the water depth parameter, $\mathrm{Fe} / \mathrm{Mn}$, as the climate parameter. In order to divide the Paleoenvironment unit along the vertical direction in a more intuitive and effective way, this paper introduced the principle of integrated prediction error filter analysis (INPEFA), and applied the Cyclolog software to processing the data of each Paleoenvironment parameter curve to plot the INPEFA curve (Fig. 2). The main workflow can be described as below. First, the maximum entropy spectral analysis (MESA) was performed to obtain the autocorrelation function. Afterwards, the prediction

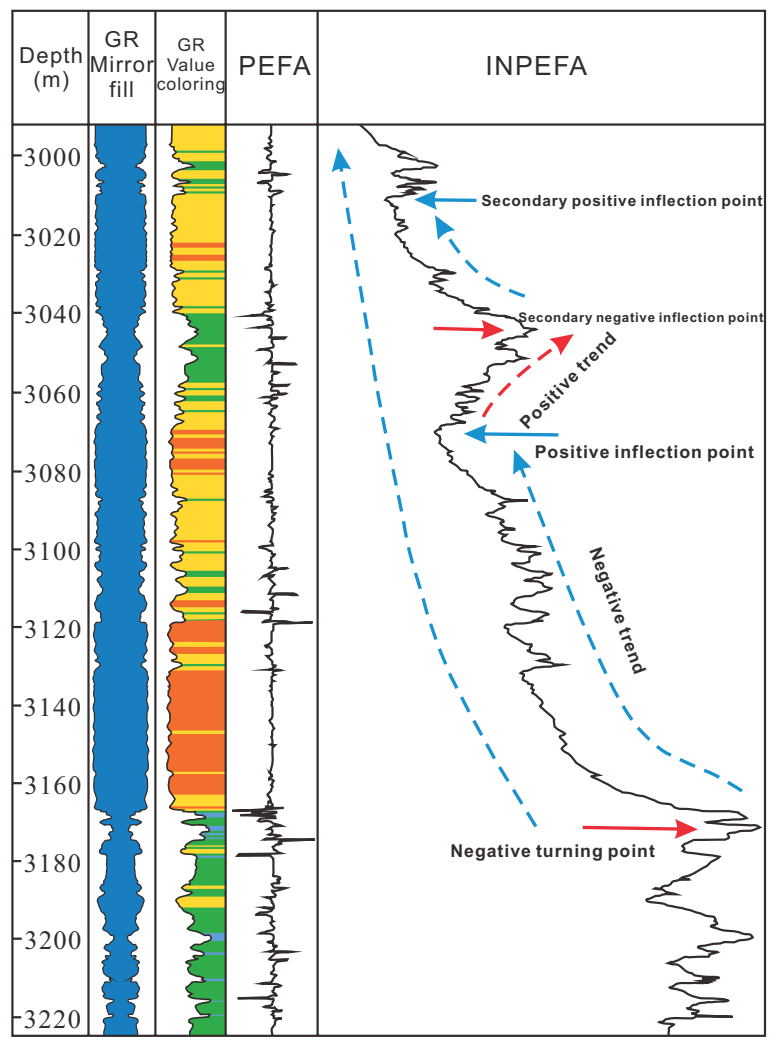

Fig. 2. Implications of the characteristics of PEFA and INPEFA curves (modified from Nio et al. (2005)).

error filter analysis (PEFA) was conducted to get the difference between the MESA predicted value and the true value at the corresponding depth point. Finally, the PEFA curve is processed to plot the INPEFA curve. Through the presented 
workflow, the $55 \mathrm{~m}$ long continuous Paleoenvironment parameter curve (corresponding to the depth window of 2315-2370 $\mathrm{m}$ for processing) was processed using the Cyclolog software to generate the INPEFA curve. The resultant curve can directly visualize the variation trends of the Paleoenvironment parameters, among which the Paleosalinity, water depth and climate parameters show basically consistent patterns of the INPEFA curves.

\subsection{TOC and rock pyrolysis analysis}

Total organic carbon (TOC) content and rock pyrolysis analysis were completed in the CNPC Key Laboratory of Petroleum Geochemistry. Firstly, the sample was ground to 100 mesh particles, of which one gram was taken for TOC measurement using the CS-i carbon/sulfur analyzer, in accordance with the China's national standard GB/T19145-2013 (Xu et al., 2003). The rock pyrolysis analysis was carried out, according to China's national standard GB/T18602-2001 (Wu et al., 2001). The sample particle size is 100 mesh and the sample mass was also about one gram, and the instrument was Rock Eval 6.

\subsection{Mineralogy analysis}

Mineralogy analysis was performed using the X-ray diffraction mineral analysis method in the CNPC Key Laboratory of Oil and Gas Reservoirs. The samples are 200-mesh, with the working voltage of $45 \mathrm{kV}$ and the working current of $150 \mathrm{~mA}$. The analysis was carried out using Rigaku TRR in accordance with China's petroleum industry standard SY/T 5163-2010 (Zeng et al., 2010).

\subsection{Reservoir storage capacity}

Field-emission scanning electron microscopy (FE-SEM) was completed in the CNPC Key Laboratory of Oil and Gas Reservoirs. Firstly, the samples were cut into a cube of $1 \mathrm{~cm}$ $\times 1 \mathrm{~cm} \times 0.5 \mathrm{~cm}$. After mechanical fine polishing, the surface of the sample was then ion beam milled for three hours using the Leica RES 102 ion beam milling device. Subsequently, the surfaces of the sample were carbon-coated and were used for high-resolution imaging with the adoption of the Apreo FESEM. The working voltage was $2 \mathrm{kV}$ and the working distance was $4 \mathrm{~mm}$.

The nitrogen adsorption at low temperature was completed in Peking University. The instrument was the ASAP2020 specific surface area analyzer, and the shale sample tested was 200-mesh powder. The Brunauer-Emmett-Teller (BET) specific surface area was analyzed. Moreover, the pore volume was calculated, and the equivalent pore distribution was quantitatively analyzed, according to the desorption curve determined by the Barret-Joyner-Halenda (BJH) theory.

\section{Results}

\subsection{Vertical distribution characteristics of elements}

The results of elemental analysis show that the content of $\mathrm{Si}, \mathrm{Al}$ and $\mathrm{Fe}$ is the highest, while that of $\mathrm{Mg}, \mathrm{K}$ and
$\mathrm{Ca}$ is relatively low. Specifically, the $\mathrm{Si}$ content is of $0.47 \%$ $38.4 \%$, with an average of $9.1 \%$; the Ca content is $0.23 \%$ $39 \%$, with an average of $2.68 \%$; the $\mathrm{Al}$ content is $0.12 \%$ $12.04 \%$, with an average of $5.29 \%$; the $\mathrm{Mg}$ content is $0.37 \%$ $2.33 \%$, with an average of $0.47 \%$; the $\mathrm{K}$ content is $0.1 \%$ $3.72 \%$, with an average of $2.15 \%$. $\mathrm{Ca}$ and $\mathrm{Mg}$ are the main elements of carbonate minerals, while $\mathrm{Al}, \mathrm{Si}$ and $\mathrm{K}$ are the main elements of terrigenous clastic minerals. From bottom to top, the distribution of $\mathrm{Ca}, \mathrm{Mg}, \mathrm{Al}, \mathrm{Si}$ and $\mathrm{K}$ show no obvious increasing or declining trends, and the relative changes of element content at different depths are small (Fig. 3), which indicate that the relative content of terrigenous clasts is relatively stable from bottom to top during the formation of Qing 1 member.

\subsection{Paleoenvironment characteristics}

Fig. 4 showed the Paleoenvironment of the Qing 1 member, and the Qing 1 member is deposited in a freshwater environment with some local zones of slightly salinized water. During its deposition, the climate is humid, with arid climate intermittently occurring in local areas. The water depth varies greatly, from semi-deep water to deep water. The redox condition is weakly-intensively reduced, which changes frequently along the vertical direction (Fig. 4). So as to further analyze the vertical Paleoenvironment changes of the Qing 1 member, seven Paleoenvironment units are divided from top to bottom, mainly based on the Paleowater depth and redox curves, combined with another two Paleoenvironment curves.

Unit 1 is mainly composed of shales, with thin inter-beds of dolostone, limestones, and siltstones. Ostracoda, pyrite, and calcite are observed in the lamination of shales. The water depth has undergone a complete cycle from deep to shallow, associated with increasing salinity. The reducibility is declining, while there is no obvious climate change and yet an overall transition from arid to humid.

Unit 2 is mainly composed of laminated shales. Dolostones and siltstones mainly occur at the bottom, while their thickness is much smaller than those of Unit 1. The shales are found with laminations and scattered distribution of organisms, ostracoda, calcareous laminae and dolomite nodules. Unit 2 represents a highly-reducing and arid environment, with slightly increased salinity. The water depth keeps relatively stable.

Unit 3 mostly consists of grey shales and calcareous shales. Flat calcite laminae thinner than $1 \mathrm{~mm}$ and scale-like laminations are observed and high-angle fractures are filled with calcites. From bottom to top, the reducibility is growing, with declining salinity. The water depth remains deep and stable, and the climate is semi-humid.

Unit 4 is dominated by shales with well-developed ostracoda laminaes. From bottom to top, the Paleoenvironment experiences a process characterized by growth of water depth, salinity reduction and reducibility enhancement. The Paleoenvironments between Units 3 and 4 are separated by rapid changes, especially in the degrees of humidity. Unit 4 generally represents a humid environment, while Unit 3 and its overlying units stand for the relatively arid environment.

Unit 5 is mostly composed of laminated shales, with 


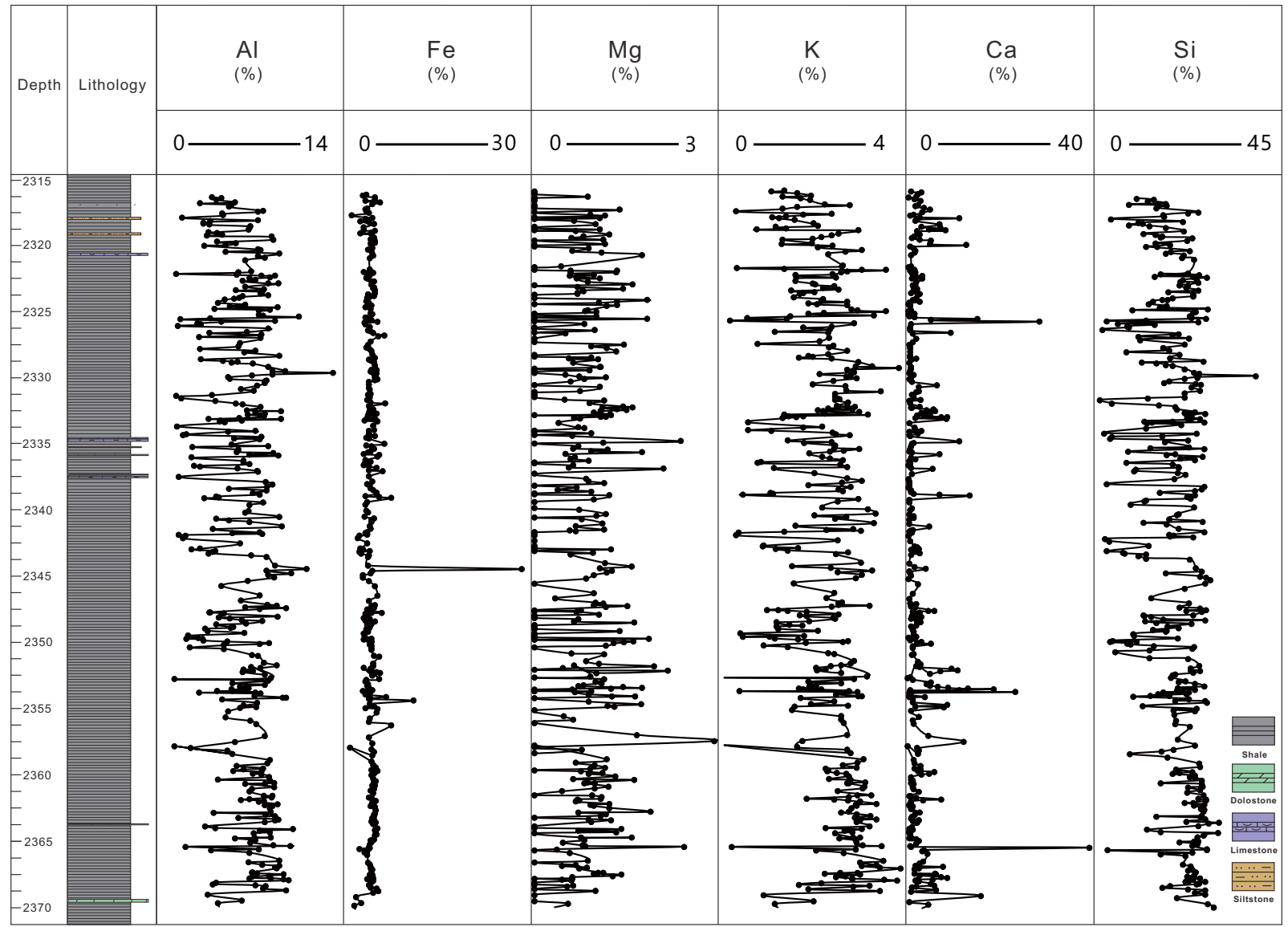

Fig. 3. Vertical distribution of main elements in Well A.

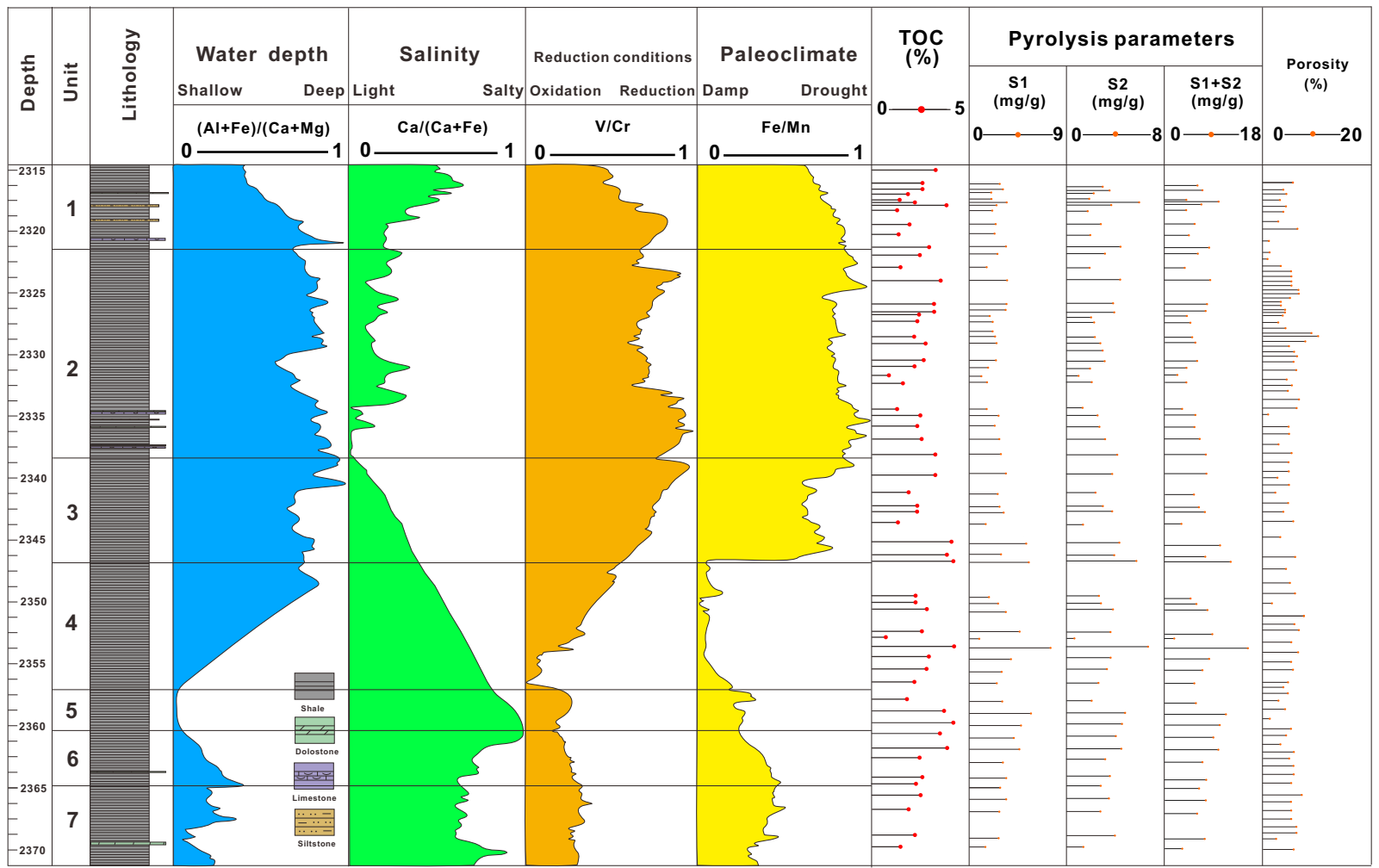

Fig. 4. Paleoenvironmental curves, organic geochemistry, porosity, and mineral composition of Qing 1 member, Well A. 
Table 1. Statistics of mineral composition, organic geochemistry and reservoir properties of different units of the Qing 1 member, Well A.

\begin{tabular}{lllllllllllllllll}
\hline $\begin{array}{l}\text { Paleo } \\
\text { enviro } \\
\text { nment Unit }\end{array}$ & \multicolumn{4}{c}{ Quartz } & $\begin{array}{l}\text { K- } \\
\text { feldspar }\end{array}$ & $\begin{array}{l}\text { Plagio- } \\
\text { clase }\end{array}$ & Calcite Pyrite & $\begin{array}{l}\text { Iron } \\
\text { dolomite }\end{array}$ & $\begin{array}{l}\text { Clays } \\
(\%)\end{array}$ & $\begin{array}{l}\text { TOC } \\
(\%)\end{array}$ & $\begin{array}{l}\mathrm{S}_{1} \\
(\mathrm{mg} / \mathrm{g})\end{array}$ & $\begin{array}{l}\mathrm{S}_{2} \\
(\mathrm{mg} / \mathrm{g})\end{array}$ & $\begin{array}{l}\text { Pore } \\
\text { volume } \\
\left(\mathrm{cm}^{3} / \mathrm{g}\right)\end{array}$ & $\begin{array}{l}\text { BET } \\
\text { SSA } \\
\left(\mathrm{m}^{2} / \mathrm{g}\right)\end{array}$ & $\begin{array}{l}\text { Porosity } \\
(\%)\end{array}$ & $\begin{array}{l}\text { DLR }(\Omega \cdot \mathrm{m}) \\
\text { DDLR } \\
(\Omega \cdot \mathrm{m})\end{array}$ \\
\hline Unit 1 & 28.05 & 1.03 & 11.85 & 9.36 & 2.49 & 0.20 & 47.03 & 2.18 & 2.62 & 3.25 & 0.071 & 17.30 & 7.39 & $0.027-0.053$ & 0.041 \\
Unit 2 & 28.36 & 1.15 & 10.65 & 2.00 & 3.03 & 2.83 & 51.99 & 2.44 & 2.57 & 2.96 & 0.078 & 21.98 & 8.29 & $0.031-0.058$ & 0.043 \\
Unit 3 & 29.65 & 0.96 & 7.59 & 1.75 & 3.18 & 1.85 & 55.03 & 2.89 & 3.70 & 3.83 & 0.069 & 15.88 & 8.03 & $0.031-0.057$ & 0.046 \\
Unit 4 & 29.51 & 1.13 & 7.64 & 3.76 & 1.21 & 0.58 & 49.94 & 2.53 & 3.74 & 3.59 & 0.029 & 3.96 & 9.38 & $0.037-0.071$ & 0.052 \\
Unit 5 & 25.73 & 0.55 & 5.03 & 4.75 & 2.68 & 8.85 & 45.15 & 3.29 & 4.88 & 4.16 & 0.058 & 11.80 & 7.44 & $0.023-0.044$ & 0.036 \\
Unit 6 & 32.20 & 0.95 & 6.98 & 4.63 & 2.83 & 0 & 52.43 & 2.84 & 3.95 & 3.79 & 0.079 & 14.84 & 8.45 & $0.045-0.052$ & 0.048 \\
Unit 7 & 32.90 & 1.03 & 6.08 & 6.73 & 2.43 & 0 & 50.85 & 2.05 & 3.05 & 3.16 & 0.064 & 9.54 & 9.03 & $0.029-0.077$ & 0.051 \\
\hline
\end{tabular}

Note: BET SSA is BET specific surface area, DLR is deep lateral resistivity, and ADLR is average deep lateral resistivity.

development of pyrite and ostracoda laminae, and it represents the relatively shallowest water depth of the Qing 1 member, corresponding to the highest water salinity. Compared with Unit 4, Unit 5 has improved reducibility and aridness, which are yet stable within the unit.

Unit 6 is mainly grey shales with observed laminations, and it represents a process in which both water depth and salinity gradually increase, and meanwhile reducibility and climate aridness decrease slightly.

Unit 7 is mainly composed of shales, with local dolostone inter-beds. Grey ostracoda laminae and dolomite lens can be observed. The sedimentary environment is relatively stable in this unit, associated with basically constant reducibility, salinity and aridness, and slightly variation of water depth.

\subsection{Geochemistry, mineralogy and pore structure of Unit 1 to Unit 7}

\subsubsection{Organic geochemical characteristics}

In view of TOC, Units 5 and 3 have the highest values. The TOC values of Unit 5 are mostly of $1.3 \%-4.3 \%$, averaging $3.29 \%$. Units 6,2 , and 4 present the second largest values, mostly ranging from $1.5 \%$ to $3.8 \%$, with an average of about $2.89 \%$. The TOC values of Units 1 and 7 are relatively low. Although some samples of these two units present TOC values exceeding 3.5\%, the average TOC of Units 1 and 7 are $2.18 \%$ and $2.05 \%$, respectively (Fig. 5(a), Table 1).

The distribution of $S_{1}$ values of different units present consistent with that of TOC. The $S_{1}$ value of Unit 5 is the highest, mostly ranging from 3.8 to $7.8 \mathrm{mg} / \mathrm{g}$, with an average of $4.88 \mathrm{mg} / \mathrm{g}$. Units 3,6 , and 4 have the second largest values, mainly lying between 3 and $7 \mathrm{mg} / \mathrm{g}$, with an average of 3.7 $\mathrm{mg} / \mathrm{g}$. Units 1,2 , and 7 have the least $\mathrm{S}_{1}$ content, mostly ranging from 1 to $4 \mathrm{mg} / \mathrm{g}$ and averaging about $3.0 \mathrm{mg} / \mathrm{g}$ (Fig. 5(b), Table 1).

\subsubsection{Mineral composition}

The content variations of clay and non-clay minerals among the seven units are compared, and the results are shown below:

\section{(1) Non-clay minerals}

Non-clay minerals include quartz, calcite, K-feldspar, and plagioclase (Figs. 5(c)-5(f)). The K-feldspar content is relatively low, mostly of $0.5 \%-1.8 \%$. Although the content of different units varies, the variation magnitudes are relatively small (Fig. 5(e), Table 1). From Unit 1 to Unit 7, the total quartz content increases gradually, except for Unit 5 with the minimum quartz content of only 25\% (Fig. 5(c), Table 5). The calcite content gradually increases from Unit 2 to Unit 7. The calcite content of Unit 1 is the highest, mainly of $2 \%-15 \%$, with the maximum value up to about $30 \%$, which is consistent with the high development ratio of dolostones and limestones in Unit 1 (Figs. 5(d) and 6, Table 1). For plagioclase, it presents the variation trend opposite to those of quartz and calcite-from Unit 1 to Unit 7, its content gradually decreases (Fig. 5(f)).

\section{(2) Clay minerals}

The clay minerals content in the Qing 1 member is high. The XRD results reveal that the clay mineral content is mainly between $40 \%$ and $60 \%$, averaging more than $50 \%$ (Table 1). From Unit 1 to Unit 7, the clay mineral content firstly increases and then declines (Fig. 5(g)), with that of Unit 3 slightly higher than those of the other units. The illite content is generally stable among Units 1-7, accounting for more than $60 \%$ of the total clay minerals, with slightly smaller values found in Units 2 and 6 (Fig. 5(h)). In terms of chlorite, Unit 1 presents the maximum content, while the content values generally rise from Unit 2 to Unit 7 (Fig. 5(i)). The content of the smectite/illite mixed layer in Units 2 and 6 are relatively high, averaging more than $20 \%$, while the other units present relatively low values, mostly less than $20 \%$ (Fig. 5(j)). From the perspective of the vertical distribution characteristics of clay minerals, the illite and chlorite show a mirror-image relationship with each other, with respect to their content, and so do the total clay minerals and the smectite/illite mixed layers.

\subsubsection{Pore structure}

\section{(1) SEM results}

The high-resolution SEM analysis of the seven units reveals similarity of the two-dimensional pore development characteristics among the seven units. The pore types include intra-granular pores of illites (Figs. 6(a) and 6(d)), pyrites 

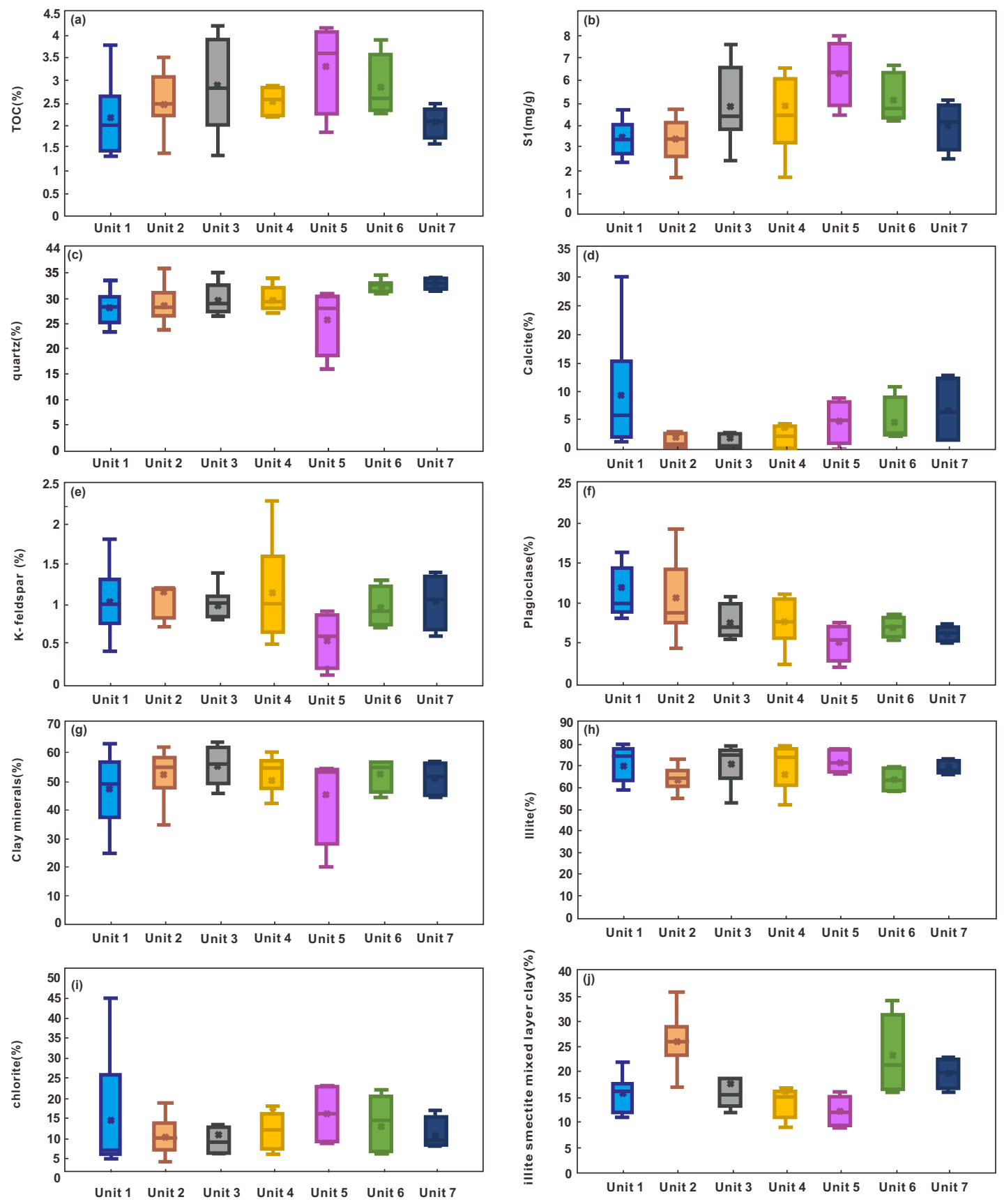

Fig. 5. Comparison of organic geochemistry and mineral composition among different Paleoenvironmental units. (a): TOC; (b): $\mathrm{S}_{1}$; (c): quartz; (d): calcite; (e): potassium feldspar; (f): plagioclase; (g): total clay minerals; (h): relative content of illite in clay minerals; (i): relative content of chlorite in clay minerals; (j): relative content of the smectite/illite mixed layers in clay minerals.

(Fig. 6(b)), plagioclases (Fig. 6(c)), and the smectite/illite mixed layers (Fig. 6(e)), calcite dissolution pores (Fig. 6(f)), and a small amount of organic matter pores (Figs. 6(g)-6(i)). Among them, the intra-illite pores are the most important type, characterized by mutual interweaving and mineral filling (Figs. 6(a), 6(d) and 6(f)). The intra-smectite/illite mixed layers pore presents the characteristic along-layer distribution (Fig. 6(e)). Similar to the Triassic Chang 7 member in the Ordos Basin and the Permian Lucaogou Formation in the Junggar Basin (Wu et al., 2015, 2019), the development of organic pores in Qing 1 member is limited, mainly in three forms: (i) isolated pores in blocky organic matter (Fig. 6(g)), (ii) pores between organic matter and matrix minerals (Fig. 6(h)), and (iii) fractures inside organic matter and between matrix minerals (Fig. 6(i)).

\section{(2) Nitrogen adsorption results}

The nitrogen adsorption results show that there are obvious differences in the pore structure among the seven units (Fig. 7). Specifically, Units 2 and 6 have the best pore systems. The BJH pore volume is of $0.078-0.079 \mathrm{~cm}^{3} / \mathrm{g}$, and the BET specific surface area is of 14.84-21.98 $\mathrm{m}^{2} / \mathrm{g}$ (Table 1, and Figs. 7 (b) and 7(f)). The BJH pore volumes of Units 1 and 3 is slightly smaller, lying between 0.069 and $0.071 \mathrm{~cm}^{3} / \mathrm{g}$, while 

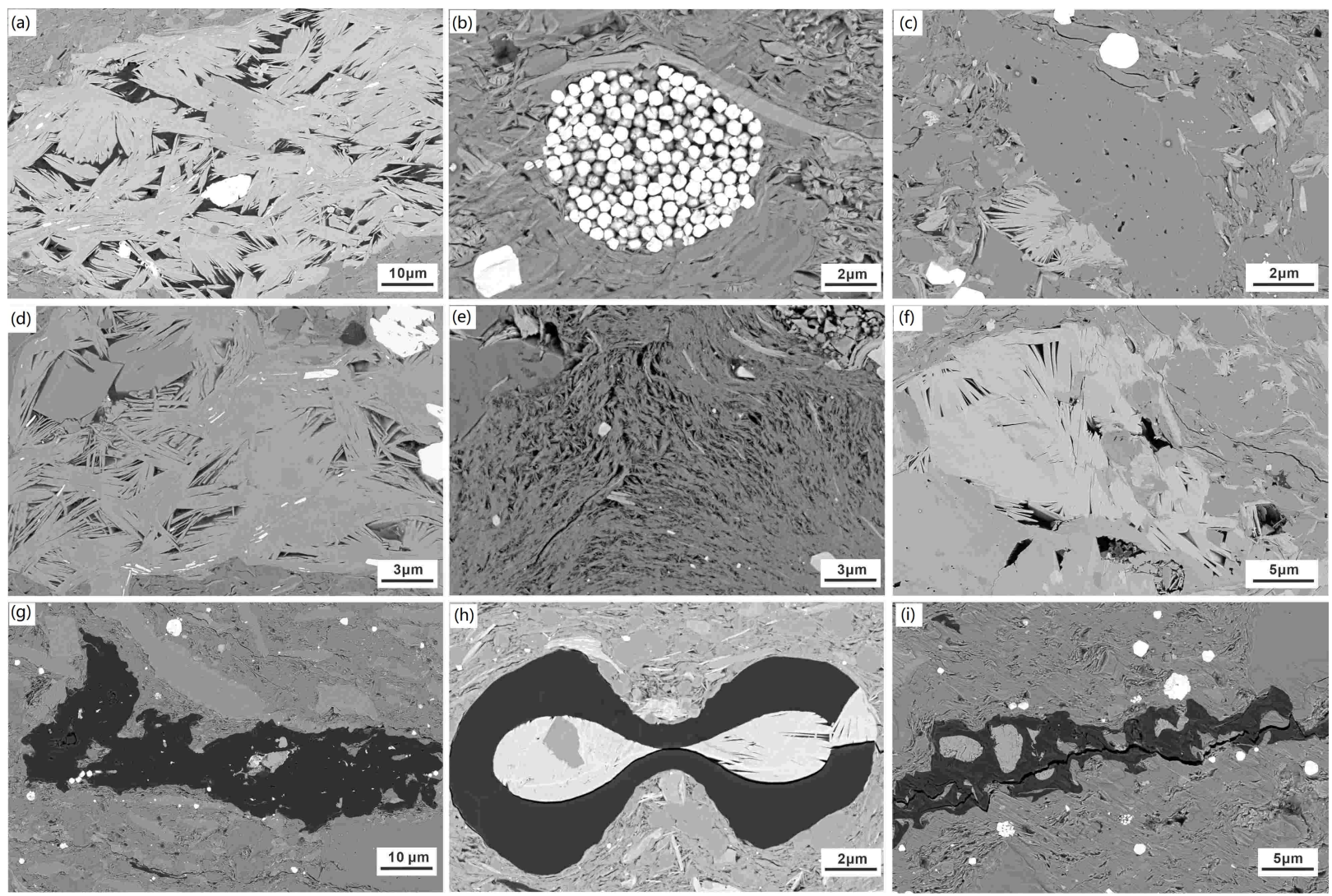

Fig. 6. Typical SEM photos of pore structures in different units of Well A. (a): Intra-illite pores, Unit 1; (b): intra-pyrite pores, Unit 2; (c): intra-plagioclases and intra-illite pores, Unit 3; (d): intra-illite pores, with inter-calcite pores, Unit 4; (e): intra-smectite/illite mixed layer pores, Unit 5; (f): calcite dissolution pores and intra-illite pores, Unit 6; (g): blocky organic matter, with isolated internal pores, Unit 7; (h): organic matter, with inside filling of authigenic calcite and illite, and pores between organic matter and matrix minerals, Unit 3; (i): organic matter and intra-illite pores, with fractures occurring along the interior of organic matter and the interface between organic matter and matrix minerals, Unit 5.

the BET surface area is of $15.88-17.30 \mathrm{~m}^{2} / \mathrm{g}$ (Table 1 and Figs. $7(\mathrm{a})$ and $7(\mathrm{c}))$. Units 5 and 7 present the BJH pore volumes of $0.058-0.064 \mathrm{~cm}^{3} / \mathrm{g}$, and the BET surface areas of 9.54-11.80 $\mathrm{m}^{2} / \mathrm{g}$ (Table 1, Figs. 7(e) and $7(\mathrm{~g})$ ). Unit 4 is associated with poor pore development. Its $\mathrm{BJH}$ pore volume is $0.029 \mathrm{~cm}^{3} / \mathrm{g}$, and the BET specific surface area is $3.96 \mathrm{~m}^{2} / \mathrm{g}$ (Table 1 and Fig. 7(d)), which complies with its extensive development of organic matter and fewer pores.

Although the specific pore volumes of the seven units are different, the seven units have similarities with respect to pore size distribution. The pore sizes are mostly of $40-53 \mathrm{~nm}$, and the corresponding pores account for more than $25 \%$ of the total storage space (Figs. 7(a)-7(g)). Except for Unit 4 found with a unimodal pore size distribution (Fig. 7(d)), the rest six units all have bimodal pore size distribution, and the second peak of pore size is located at 3-4 nm (Figs. 7(a)-7(c) and $7(\mathrm{e})-7(\mathrm{~g}))$.

\section{Discussion}

\subsection{Paleoenvironment evolution}

Previous studies show that for fine-grained sedimentary rocks such as organic-rich shales, Paleoenvironment not only affects the distribution of organic matter, but also affects the physical properties of reservoirs (Manzullo and Harris,
1992). The Paleoclimate is one of the most important factors controlling the water level fluctuation of the lacustrine basin, water salinity, types of biogenic organic matter and sedimentary facies. The results demonstrate that the deposition of the Qing 1 member is generally associated with a deep-water, humid, and reducing freshwater-brackish water environment, and yet the Paleoenvironment still presents frequent variation vertically from bottom to top (Fig. 4).

In general, the Paleoenvironment of the Qingshankou Formation can be divided into three stages: (i) The first stage is represented by Units 5,6 , and 7, with relatively shallow water depth, high water salinity, and high oxygen content resulting in relatively strong oxidizability. (ii) The second stage includes Units 3 and 4, which represents a transition process of the sedimentary environment of the Qing 1 member. In this stage, the water depth gradually increases, and meanwhile the water salinity and oxygen content gradually decline, leading to enhanced reducibility. (iii) The third stage consists of Units 1 and 2. Although in this stage the water depth has experienced three sub-cycles from deep to shallow, the water depth is deep on an overall basis, with relatively low water salinity and high reducibility (Fig. 4).

It should be noted that there is a certain contradiction between the results of humidity/aridness parameters and those of the Paleowater depth, salinity, and redox parameters (Perlmut- 

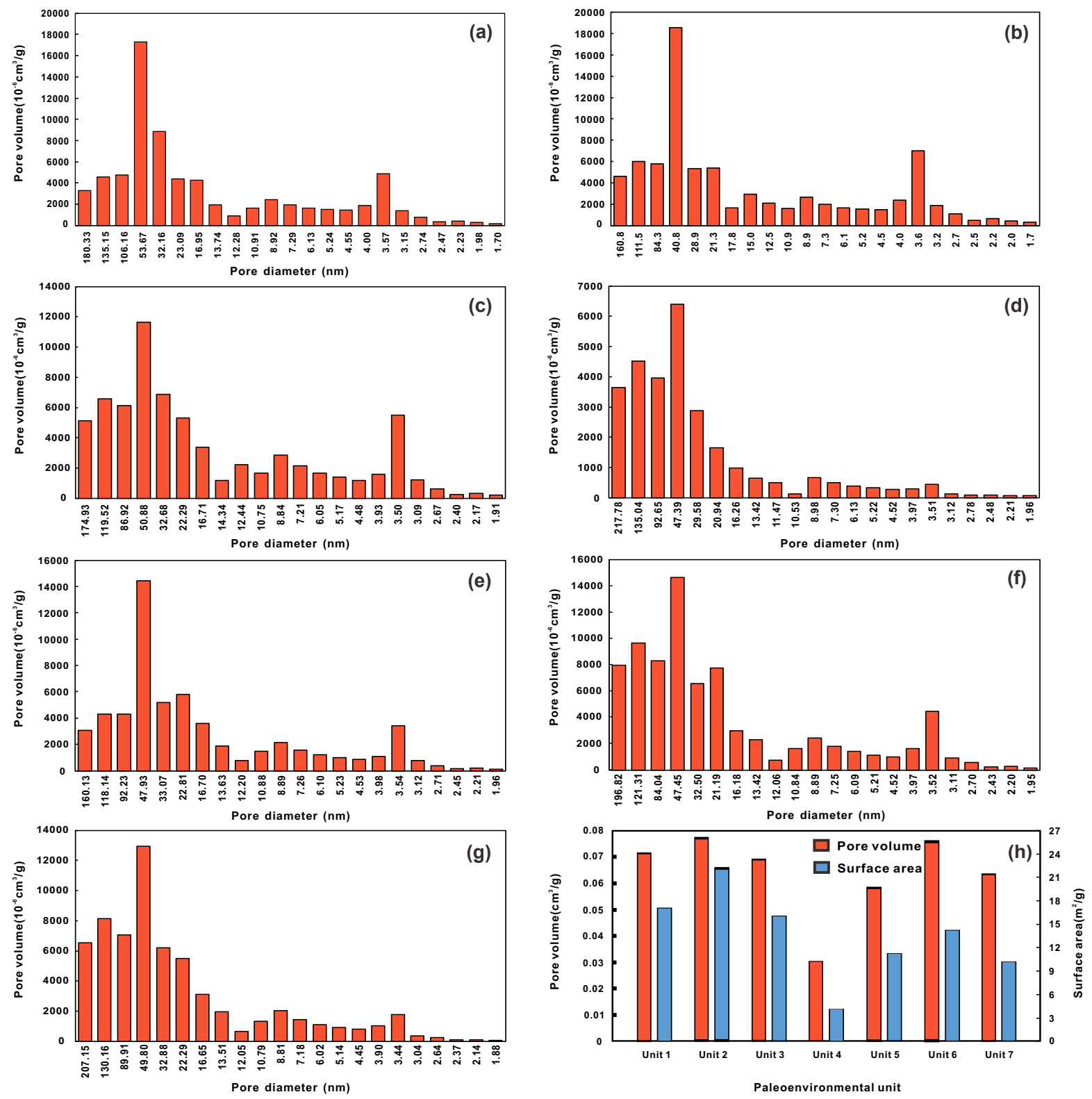

Fig. 7. Pore structure from nitrogen adsorption data of Units 1-7. (a)-(g): Pore size distribution of Units 1-7; (h): BJH pore volume and BET specific surface area of Units 1-7.

ter and Matthews, 1990; Talbot and Kelt, 1990; Katz and Lin, 2014). Due to the limitation of the collected XRF element data, this research investigates and restores the humidity/aridness of the Paleoenvironment only using the Fe/Mn ratio, which may compromise the accuracy of the results (Lee, 1992; Jones et al., 1994; Loucks et al., 2012). Therefore, the parameters of environmental humidity/aridness need to be further studied.

\subsection{Relationship between the Paleosedimentary environment and shale quality}

Previous studies showed that a variety of factors can affect organic matter accumulation, including high organic matter input (Gallego et al., 2007; Walls et al., 2011), oxygen deficiency of the stratified water column (Meyers and Ishiwatari, 1995), and the combination of these two factors (Tyson, 2005;
Sonnenberg and Pramudito, 2009; Roy and Roser, 2013). These factors are strongly influenced by the environments, including climate, redox conditions, salinity, and water depth. Humid climate can lead to water bloom, and high salinity of lake water can affect bio-distribution and create favorable conditions for organic matter preservation in the lower part of water. The Paleoenvironmental parameters of the Qingshankou Formation show that Paleosalinity is closely related to the TOC content. Units 5 and 6 with relatively high salinity have obviously higher TOC values (Table 1, Fig. 4). In addition, the relatively high water depth and reducibility of Units 1 and 2 also provide positive contribution to high TOC (Fig. 5).

In terms of the mineralogy of lacustrine shale systems, the evolution of the Paleoenvironment also plays an important role. From Units 7 to 1 , the content of carbonate minerals such 
as calcite decreases gradually, with the shallower water depth and higher salinity, which is consistent with previous studies on carbonate precipitation. At the same time, with the increase of water salinity, the chlorite content rises, and yet the illite content declines decreases correspondingly (Fig. 5).

The storage space of the Qingshankou Formation is dominated by intra-clay mineral pores, associated with development of intra-pyrite pores and calcite dissolution pores and limited development of organic matter pores. In this study, we collected porosity data from Daqing oilfield. The data indicated that no clear relationship exists between porosity and Paleoenvironmental parameters (Table 1). Moreover, these porosity data are not consistent with the BJH pore volumes. For example, the Unit 4 have the highest porosity value, while the BJH pore volume is relatively low (Table 1, Fig. 7(h)). This data may indicate the obvious differences of variable methods (Wu et al., 2019; Li et al., 2020). Only pores with diameter ranging from 2 to $100 \mathrm{~nm}$ were detected during the nitrogen analysis, and the whole pore volume was detected during the helium porosity measurement. Such understanding is basically consistent with the research on the reservoirs of the Permian Lucaogou Formation in the Junggar Basin, the Triassic Chang 7 member in the Ordos Basin, and the Paleogene Kong 2 member in the Bohai Bay Basin (Zhao et al., 2018). Compared with the shale of the marine Silurian Longmaxi Formation, the proportion of organic matter pores in the total porosity of the Qing 1 member is smaller, which is directly related to the organic matter maturity, lower than that of the Longmaxi Formation.

\section{Conclusions}

Based on the high-precision ED-XRF element analysis, this paper targets Well A in the central part of the Songliao Basin, reconstracts the sedimentary environment of the Qing 1 Member, and investigates the correlation between the Paleoenvironment and the characteristics of organic geochemistry, mineralogy, and reservoir properties, by combining the XRD analysis, TOC measurement, rock pyrolysis, SEM imaging, and nitrogen adsorption testing. The conclusions are listed as follows,

1) The Paleoenvironment during deposition of the Qing 1 member is characterized by fresh-brackish water, semi deep-deep water depth, and strong reducibility. Based on the INPEFA method, the Qing 1 member is divided into seven units, which, from bottom to top, represent a process of growth of water depth, decline of water salinity, and growth of reducibility.

2) The Paleosalinity of the Qing 1 member is positively correlated with TOC, $S_{1}$ and carbonate mineral content, and the influences of water depth and redox conditions are smaller than those of Paleosalinity. From Unit 7 to Unit 1, the content of carbonate minerals and chlorite grows, while the total amounts of plagioclase and clay minerals decrease slightly.

3) The pore structure of the Qing 1 member shows no clear pattern in relative to the Paleoenvironment. The pore types are mainly intra-granular pores of illite, smec- tite/illite mixed layers, plagioclase, and pyrite, associated with development of calcite dissolution pores, and limited development of organic matter pores. From Unit 7 to Unit 1 , the pore structure is bimodal, with dominant pore diameters of 40-53 nm. Unit 4, representing a transition stage of the Paleoenvironment of the Qing 1 member, is found with poor development of pores.

\section{Acknowledgement}

We thank China National Petroleum Corporation's permission to publish this paper. This work is sponsored by Natural Science Foundation of China (Nos. 42072187, 42090025), and CNPC Key Project of Science and Technology (Nos. 2019E-26, 2021DQ0405). We thank members of our research community from Daqing Oilfield and RIPED for the data and ideas they contributed.

\section{Conflict of interest}

The authors declare no competing interest.

Open Access This article is distributed under the terms and conditions of the Creative Commons Attribution (CC BY-NC-ND) license, which permits unrestricted use, distribution, and reproduction in any medium, provided the original work is properly cited.

\section{References}

Attar, A. E., Pranter, M. J. Regional stratigraphy, elemental chemostratigraphy, and organic richness of the Niobrara Member of the Mancos Shale, Piceance Basin, Colorado. AAPG Bulletin, 2016, 100(3): 345-377.

Bohacs, K. M., Carroll, A. R., Neal, J. E., et al. Lake-basin type, source potential, and hydrocarbon character: An integrated sequence-stratigraphic geo-chemical framework (in lake basins through space and time). AAPG Studies in Geology, 2000, 46: 3-34.

Dean, W. E., Gardner, J. V., Piper, D. Z., et al. Inorganic geochemical indicators of glacialinterglacial changes in productivity and anoxia on the California continental margin. Geochimica et Cosmochimica Acta, 1997, 61: 4507-4518.

Dill, H., Teschner, M., Wehner, H., et al. Petrography, inorganic and organic geochemistry of Lower Permian carbonaceous fan sequences ("Brand-schiefer Series")Federal Republic of Germany: Constraints to their palaeogeography and assessment of their source rock potential. Chemical Geology, 1988, 67(3-4): 307-325.

Feng, Q., Xu, S., Xing, X., et al. Advances and challenges in shale oil development: A critical review. Advances in Geo-Energy Research, 2020, 4(4): 406-418.

Feng, Z., Huo, Q., Wang, X., et al. Organic geochemical characteristics and paleosedimentary environments of the source rocks in member 1 of Qingshankou Formation. Petroleum Geology \& Oilfield Development in Daqing, 2015, 34(4): 2-7. (in Chinese)

$\mathrm{Fu}$, J., Niu, X., Dan, W., et al. The geological characteristics and the progress on exploration and development of shale oil in Chang7 Member of Mesozoic Yanchang Formation, Ordos Basin. China Petroleum Exploration, 2019, 24(5): 601-614. (in Chinese) 
Gallego, T. D., Martinez, R. F., Paytan, A., et al. PlioceneHolocene evolution of depositional conditions in the eastern Mediterranean: Role of anoxia vs. productivity at time of sapropel deposition. Palaeogeography Palaeoclimatology Palaeoecology, 2007, 246: 424-439.

Gao, R. Characteristics of petroleum generation and expulsion in abnormal pressure shale zones and the formation of fractured shale reservoirs. Petroleum Geology \& Oilfield Development in Daqing, 1984, 3(1): 160-167. (in Chinese)

He, W., Meng, Q., Zhang, J., et al. Controlling factors and their classification-evaluation of Gulong shale oil enrichment in Songliao Basin. Petroleum Geology \& Oilfield Development in Daqing, 2021, 40(5): 1-12. (in Chinses)

Hou, L., Ma, W., Luo, X., et al. Characteristics and quantitative models for hydrocarbon generation-retention-production of shale under ICP conditions: Example from the Chang 7 member in the Ordos Basin. Fuel, 2020, 279: 118497.

Hou, L., Ma, W., Luo, X., et al. Hydrocarbon generationretention-expulsion mechanism and shale oil producibility of the permian lucaogou shale in the Junggar Basin as simulated by semi-open pyrolysis experiments. Marine and Petroleum Geology, 2021, 125: 104880.

Jones, B., Manning, D. A. C. Comparison of geochemical indices used for the interpretation of palaeoredox conditions in ancient mudstones. Chemical Geology, 1994, 111(1-4): 111-129.

Katz, B., Lin, F. Lacustrine basin unconventional resource plays: Key differences. Marine and Petroleum Geology, 2014, 56(3): 255-265.

Koch, J. T., Frank, T. D., Bulling, T. P., et al. Stableisotope chemostratigraphy as a tool to correlate complex Mississippian marine carbonate facies of the Anadarko shelf, Oklahoma and Kansas. AAPG Bulletin, 2014, 98(6): 1071-1090.

Lee, C. Controls on organic carbon preservation: The use of stratified water bodies to compare intrinsic rates of decomposition in oxic and anoxic systems. Geochimica et Cosmochimica Acta, 1992, 56(8): 3323-3335.

Li, K., Kong, S., Xia, P., et al. Microstructural characterization of organic matter pores in coal-measure shale. Advances in Geo-Energy Research, 2020, 4(4): 372-391.

Liu, B., Shi, J., Fu, X., et al. Petrological characteristics and shale oil enrichment of lacustrine fine-grained sedimentary system: A case study of organic-rich shale in first member of Cretaceous Qingshankou Formation in Gulong Sag, Songliao Basin, NE China. Petroleum Exploration and Development, 2018, 45(5): 884-894.

Loucks, R. G., Reed, R. M., Ruppel, S. C., et al. Spectrum of pore types and networks in mudrocks and a descriptive classification for matrix-related mudrock pores. AAPG Bulletin, 2012, 96(6): 1071-1098.

Mazzullo, S. J., Harris, P. M. Mesogenetic dissolution: Its role in porosity development in carbonate reservoir. AAPG Bulletin, 1992, 76(5): 607-620.

Meyers, P. A., Ishiwatari, R. Organic matter accumulation records in lake sediments, in Physics and Chemistry of
Lakes, edited by A. Lerman., D. M. Imboden, J. R. Gat, Springer, Berlin, Heidelberg, pp. 279-328, 1995.

Nicolas, T., Thomas, J. A., Timothy, L., et al. Trace metals as palaeoredox and palaeoproductivity proxies: An update. Chemical Geology, 2006, 232(1-2): 12-32.

Nio, S. D., Brouwer, J., Smith, D., et al. Spectral trend attributeanalysis: Applications in the stratigraphic analysis of wireline logs. First Break, 2005, 23(4): 71-75.

Perlmutter, M. A., Matthews, M. D. Global cyclostratigraphy: A model, in Quantitative Dynamic Stratigraphy, edited by T. A. Cross, Prentice Hall, Englewood Cliffs, New Jersey, pp. 233-260, 1990.

Peters, K. E., Wright, T. L., Ramos, L. S., et al. Chemometric recognition of genetically distinct oil families in the Los Angeles basin, California. AAPG Bulletin, 2016, 100(1): 115-135.

Ratcliffe, K. T., Wilson, A., Payenberg, T., et al. Ground truthing chemostratigraphic correlations in fluvial systems. AAPG Bulletin, 2015, 99(1): 155-180.

Rowe, H., Hughes, N., Robinson, K., et al. The quantification and application of handheld energy-dispersive X-ray fluorescence (ED-ERF) in mudrock chemostratigraphy and geochemistry. Chemical Geology, 2011, 12(23): 122131.

Roy, D. K., Roser, B. P. Climate control on the composition of Carboniferous-Permian Gondwana sediments, Khalaspir basin, Bangladesh. Gondwana Research, 2013, 23(3): 1163-1171.

Sonnenberg, S. A., Pramudito, A. Petroleum Geology of the giant elm coulee field, Williston Basin. AAPG Bulletin, 2009, 93(9): 1127-1153.

Sun, L., Liu, H., He, W., et al. An analysis of major scientific problems and research paths of Gulong shale oil in Daqing Oilfield, NE China. Petroleum Exploration and Development, 2021, 48(3): 453-463. (in Chinese)

Talbot, M. R., Kelt, K. Palaeoclimnological signatures from carbon and oxygen isotopic ratios in carbonates from organic carbon-rich lacustrine sediments. AAPG Memoir, 1990, 50(6): 99-112.

Tyson, R. V. The "productivity versus preservation" controversy: Cause, flaws and resolution, in The Deposition of Organic-carbon-rich Sediments: Models, Mechanisms, and Consequences, edited by N. B. Harris, SEPM Special Publication, pp. 17-33, 2005.

Walls, J. D., Diaz, E., Derzhi, N., et al. Eagle Ford shale reservoir properties from digital rock physics. First Break, 2011, 29(6): 97-100.

Wang, C., Feng, Z., Wu, H., et al. Preliminary achievement of the Chinese cretaceous continental scientific drilling project-SK-I. Acta Geologica Sinica, 2008, 82(1): 10-20. (in Chinese)

Wu, L., Zhang, Z., Li, B., et al. Rock pyrolysis analysis, GB/T 18602-2001, 2001. (in Chinese)

$\mathrm{Wu}, \mathrm{S}$., Zhu, R., Cui, J., et al. Characteristics of lacustrine shale porosity evolution, Triassic Chang 7 Member, Ordos Basin, NW China. Petroleum Exploration and Development, 2015, 42(2): 185-195. 
Wu, S., Zhu, R., Yang, Z., et al. Distribution and characteristics of lacustrine tight oil reservoirs in China. Journal of Asian Earth Sciences, 2019, 178: 20-36.

Xu, G., Gao, Y., Dong, S., et al. Determination of total organic carbon in sedimentary rocks, GB/T 19145-2003, 2003. (in Chinese)

Zeng, L., Wang, L., Xu, H., et al. Analysis method for clay minerals and ordinary non-clay minerals in sedimentary rocks by the X-ray diffraction, SY/T 5163-2010, 2010. (in Chinese)

Zhang, S., Cao, Y., Liu, K., et al. Characterization of lacustrine mixed fine-grained sedimentary rocks using coupled chemostratigraphic-petrographic analysis: A case study from a tight oil reservoir in the Jimusar Sag, Junggar Basin. Marine and Petroleum Geology, 2019, 99: 453472.

Zhao, X., Zhou, L., Pu, X., et al. Geological characteristics of shale rock system and shale oil exploration breakthrough in a lacustrine basin: A case study from the Paleogene 1st sub-member of Kong 2 Member in Cangdong sag,
Bohai Bay Basin, China. Petroleum Exploration and Development, 2018, 45(3): 377-388.

Zhao, Z., Littke R., Zieger, L., et al. Depositional environment, thermal maturity and shale oil potential of the Cretaceous Qingshankou Formation in the eastern Changling Sag, Songliao Basin, China: An integrated organic and inorganic geochemistry approach. International Journal of Coal Geology, 2020, 232: 103621.

Zhi, D., Tang, Y., Deng, M., et al. Geological characteristics and accumulation controlling factors of shale reservoirs in Fengcheng Formation, Mahu sag, Junggar Basin. China Petroleum Exploration, 2019, 40(3): 524-534. (in Chinese)

Zhu, R., Zou, C., Wu, S., et al. Mechanism for generation and accumulation of continental tight oil in China. Oil \& Gas Geology, 2019, 40(6): 1168-1184. (in Chinese)

Zou, C., Pan, S., Jing, Z., et al. Shale oil and gas revolution and its impact. Acta Petrolei Sinica, 2020, 41(1): 1-12. (in Chinese) 